\title{
Modern American Visual Image of Russian History
}

\author{
Lyudmila V. Belgorodskaya ${ }^{a *}$, \\ Ekaterina V. Tishchenko ${ }^{b}$ and Tatiana A. Belgorodskaya ${ }^{a}$ \\ ${ }^{a}$ Siberian Federal University \\ 79 Svobodny, Krasnoyarsk, 660041, Russia \\ ${ }^{b}$ University of the Arts London \\ 81 Sutherland, London, W92 HG Great Britain
}

Received 19.09.2014, received in revised form 04.10.2014, accepted 24.10.2014

The article is devoted to the features of Russian history visualization in American universal and historical encyclopedias of the 20-21st centuries (Britannica, the American encyclopedia, the Encyclopedia of history of Russia, etc.). The foundations and museums keeping the images used in the encyclopedias are characterized. The questions of reflecting natural, ethnic features of the country and images of political and cultural elite of the state in encyclopedic editions are considered. Finally, the work assesses the comments to the provided images.

Keywords: american encyclopedias, visual image of Russia, imagenology.

Research area: History.

\section{Introduction}

Russian historians and cross-cultural communication experts still pay little attention to the analysis of images, and the ability to learn "reading" visual texts. The "visual turn" ("pictorial turn") in humanitarian researches appeared only in the early 1980-s. The development in the history of mentalities, and then cultural history raised the interest of foreign historians to various types of images, from common graphic and pictures to extraordinary optical, mental and verbal images. Nowadays it is understood that for the research of national and social identity the visual is not less informative than the narrative (Vishlenkova, 2011, p. 16, 292).

(C) Siberian Federal University. All rights reserved

* Corresponding author E-mail address: blv.kr@yandex.ru

\section{Technologisation \\ of visual practices}

Thus, the task of a historian deviates from that of art criticism, turning to the art analysis where the aesthetic canons cease to play the essential role. For a researcher of the past, it is more important to interpret the visual text application than to assess the artifact's museum value. We may agree with the following statement of French historians: "As a rule, among historians it is not common to estimate images from the aesthetic point of view, the conditions of their emergence and use... Those are not the art forms as such that draw their attention" (Historians' Dictionary, 2011, p. 55). In this context, "mastered", "artless" and even frankly "unartful" visual images of 
the past are equally important for a historian of political and social life.

As a historical source, we used American encyclopedic editions, guided by the following reasons: editions of this type are, as a rule, well-illustrated; this type of sources is not wellstudied in Russia; the editions are of scientific, popular scientific and often strictly academic character, which excludes obvious influence on the character of the materials. These editions are accessible at Russian libraries and make a certain impact on Russia's domestic attitude.

A number of visual sources are not accessible for Russian experts, the copying of such being strictly restricted by libraries and museums; therefore, the research techniques are still poorly fulfilled and often do not match the framework of the traditional art criticism analysis. Many works by foreign artists and photographers, once created in the imperial, Soviet Russia, are often stored in foreign collections only.

\section{American encyclopedias as historical sources}

During recent years, some historical encyclopedias of Russia have been published in the USA. All-encompassing academic encyclopedias were printed by Academic International Press publishing house, specializing in reference book release. The publishing house did a grandiose deal releasing four encyclopedias about Russia: on the history of religion, naval and military affairs, literature, and also the unique "Modern Encyclopedia of Russian and Soviet History" in 60 volumes. However, we are compelled to note that in the context of the present research, due to the format, the small green volumes do not contain any illustrations, cards, or charts.

This article analyzes the visual images of Russia on the pages of the latest American editions (Britannica, the American encyclopedia) as a source, but special attention is paid to the
American thematic encyclopedia published in the early $21^{\text {st }}$ century. The studied edition was published in 2004 in 4 volumes. The total volume of the edition is 2000 pages of large format. It is present in many libraries of the world, also accessible in stock of the majority of large regional and academic libraries of Russia. The edition contains 285 black-and-white photos and 8 color turns, along with multiple cards, schemes, and tables. Even the cover of the edition is colorful and visually informative. The editorial board of the encyclopedia consisted of about 500 scientists from 16 countries, including such Russian authors as O. Ayrapetov, V. Brovkin, O. Budnitsky, L.Zakharova, and B. Mironov.

The external image of the edition was created by a group of experts responsible for the four tasks: creating a general visual image of the edition, material mapping, search of interesting photographic materials and preparation of illustration titles. Each volume contains color inserts portraying the beauty and scope of Russian peoples, art, as well as important military and political pictorials (Encyclopedia of Russian History, 2004, V. 1, Preface).

\section{Methods of research}

One may classify the historical illustrative materials on the past of Russia, used in Western reference books. According to the illustrations' compliance to historical reality, the visual materials can be divided into "firsthand" images depicting a historical era, or, in other words, primary authentic sources, and secondary visual sources. A famous Russian historian O.M. Medushevskaya called this first group the "phenomena of culture of the time". Secondary images reproduce the past after a rather long time; they attempt to simulate historical events.

In American works, the second type images are used extremely seldom as they, at large, rather 
reflect the realities of the time when they were created.

One may also apply the genre classification to the published images, dividing the visual sources into icons, portraits, caricatures, graphic works etc. All these genres are present in the studied editions. Popular scientific character of the edition defines the preferences: the priority is given to smart portraits of politicians, photos, painting reproductions; few caricatures are used, and few works use the images of sculptures.

In the present analysis, using the visual material research technique by E. Vishlenkova, we raise the following questions: 1) how we look at a source, 2) how we see the things we can see; 3) how we perceive the visible and the invisible (Vishlenkova, 2011, p. 17). The problems are solved with the methods adjusted for the perception of the Russian past by foreign scientists and readers as they see what they may see etc. Conducting external examination of an image, it is important to establish the name of its author, the history of the emergence and life of the visual image.

Some of the provided images are or were stored at Russian national museums and archives: the Hermitage Museum, the Russian museum, the Historical museum. The greatest part of the artifacts is located in Western painting collections, foreign archives and libraries. Among Western museums, the ones keeping Russian art collections or any other visual images of the events and heroes of the Russian past, are of great interest for historians and art critics.

\section{American collections \\ of Russian visual materials}

The museum in Hillwood, the USA, is distinguished for keeping and collecting thousands of artifacts connected with the Russian past.
The museum was opened according to the will of a successful American businesswoman Marjorie M. Post (1887-1973). Together with her third husband D.I. Davies (at that time, the USA Ambassador in the USSR), she lived in Moscow in 1937-1938. There M.M. Post discovered Russia and Russian art, made it a subject of her passion, and devoted the rest of her life to collecting and studying the works of Russian art. In the middle of the last century she bought a manor near Washington, and used the reconstructed 36-roomed mansion for the display of her rich collection. Later, special buildings for the library and the archive were constructed; the owner ordered to make a fine Russian-style park around the mansion. In the past, the house was also used as a venue for balls, receptions, and holidays.

It is worth mentioning that the greatest part of the images used in the latest encyclopedias on Russian history belongs to Corbis Corporation. The private corporation was founded in 1989 by Bill Gates and is located in Seattle, Washington. Now the collection holds over 100 million images and 800 thousand video clips. The collection contains many Russian materials from Bettman archive acquired in 1995, a collection of photos by Underwood \& Underwood, Hulton-Deutsch. Corbis purchased a right of digital reproduction of objects from a number of Russian museums (for instance, the Hermitage Museum). A part of the paintings on display at the museum belongs to some foreign private collections, and is reproduced with the consent of their owners.

Let us study some topics connected with the features of visual images of Russia used in Western encyclopedic works.

\section{Russia as a huge multinational country with a special development pattern}

The readers' formal awareness of the scale of the country is vividly presented by the ethnic structure of the population as reflected by visual 
anthropology. Analyzing the visual images in American encyclopedias, a researcher first pays attention to the anthropological character of images. The personalities, their interests, passions, requirements, desires "are read" from the visual texts. The visual material shows the severe nature and variety of life forms in various natural zones not as much as it reveals the Russians' strategy of survival in severe conditions. The descriptions of the photos in the Encyclopedia of Russian History reflect the topic well: "A Yakut cook peers out from a restaurant window encased in frozen snow", "Schoolchildren cross-country ski on the frozen Tura River near Tyumen", "Russian mother and her children dressed in their finest winter clothes take a sled to the nearest village to watch television". (Encyclopedia of Russian History 2004, v.4, p.1323, 1344, 1392).

At the end of the last century, Western historical science dedicated itself to detailed studies of the province history, analysis of the citizens' life, ordinary lives' story. In the 4-volume American Encyclopedia of Russian History there are dozens of such pictures, with the titles describing their visual contents: "The workers of Odessa walking at carts with flour. 1878", "The Russian peasants execute folklore music, the beginning of the $20^{\text {th }}$ century", "Peasants sift grain in the village of Shari, 560 miles to the East from Moscow", "A half of cattle in the village has leukemia, but the meat of these animals is used in food", "The student studies a newspaper through the glass in a booth of the St. Petersburg university. 1992" (Encyclopedia of Russian History 2004: 18, 601, 709, 1471).

The ethnic and confessional diversity of Russia is manifested in the multiple illustrated sketches about the people of all republics of the former USSR. Special attention is paid to the people of Siberia, the Caucasus and Central Asia.
Even modern Russians discover the Russian Empire for themselves on the pages of the Western encyclopedias. As an example, let us mention the color photos of S.M. Prokudin-Gorsky executed with a unique technology in Russia (1909-1916): the negatives of those photos are now stored at the Library of Congress of the USA (Washington).

\section{Images of Russian political imperial elite}

In the considered sources the portraits of practically all tsars and emperors of Russia are present. A number of images are little known to Russian readers and historians. Among them, there are a portrait of Ivan the Terrible facing St.Basil's Cathedral (The Bettman Archive) and a portrait of Elizabeth in her magnificent dress decorated with the "symbols of power" living among the clouds, indicating the political mind of the "cheerful Elizabeth", a representative of "Russian matriarchate", an "Amazon autocratrix"(Pierre Duflos, Stapleton Collection). The authoritative style of reign reflected in the equestrian portrait Nicholas I by A.P. Schwabe (Archivo. Iconografico, S.A./Corbis).

In the year of the $400^{\text {th }}$ anniversary of the Romanovs' House on the throne it is worth paying attention to the pictures of the dynasty representatives made by Western photographers. The English-speaking world generally identifies the Romanovs with the portraits of the Russian monarchs stored in the collection of Hillwood Museum.

Traditionally, in the biographic articles of British and American encyclopedias these portraits and photos of the Russian empresses and emperors of the $18-20^{\text {th }}$ centuries from a museum collection, rare for the Hermitage and other museums of the world, are used. In the most famous encyclopedia of the Western world, Britannica, all the portraits of Anna of Russia, Paul I, Alexander I, Nicholas I, Alexander II, 
Alexander III, Nicholas II are the exclusives from the paintings' collection of this museum (The New Encyclopaedia Britannica, 1994, v. 1, p. 242, 244, 245; v. 8, p. 684, 686).

The abundance of the artifacts connected with the last Russian emperor's family indicates M. Post's particular interest for the more recent events of political history. The collection keeps many photos and coronation souvenirs of great historical value. From several half-length portraits of the Tsar (by an unknown artist, M. V. Rundaltsov and V. Strekalovsky) the greatest interest is caused by the latest work. Vsevolod Strekalovsky represented the Tsar in a singlebreasted coat with St George's Cross on his breast. The artist was trained in a family close to the ruling elite. A former naval cadet, after the revolution the artist lived in Egypt, did shootings of the Egyptian hieroglyphs for Harvard and Chicago universities. The last days of his life he spent in America.

The portrait of the last emperor that came from his brush (without the authorship indication, which is a big rarity for Western editions) illustrates the biographic article on Nicholas II in the newest edition of the Britannica. It perfectly depicts the state of mind of the Emperor who wrote in his diary: "All around me I see treason, cowardice and deceit".

On the other hand, as Richard S. Wortman noted, in the years of World War I Nicholas II got strongly used to the role of a military person ordering as a Supreme Commander. In those years the monarch was passionate about his portraits in a military uniform with $\mathrm{St}$ George's Cross on a breast (Wortman, 2004, v. 2, p. 700). One of the last lifetime photos of the Tsar taken at the prisoner house in 1918 logically finishes the series of the "soldier's" images of the monarch.

The other Hillwood photo of Tsarevich Alexei used in encyclopedias, where he is portrayed in his military overcoat with St George's Cross and other awards on his breast, confirms the popularity of military motives in depicting the Romanovs during World War I. It is remarkable that only a week after October 17, 1915 , the St.George's award of the $4^{\text {th }}$ class was handed over to Alexei by Nicholas. In his diary, the monarch left and enthusiastic record: "The day of receiving the Cross of St. George $4^{\text {th }}$ class is unforgettable for me... The whole day after that went as in fumes!" It is possible to notice the time attributes in the portrait made after 1915.

The smart portraits used in encyclopedias and the photos of the talented authors of the last imperial modernization, such as S.Yu. Witte and P.A. Stolypin demonstrate the trueness of the words Nicholas II said in a conversation with Anna Vyrubova: “They cover me". The Imperial Household Master, General V.B. Frederiks recommended Nicholas to be photographed only on a horseback to look more imposing. The collection of video records of the Library of Congress of the USA contains a big collection of photos of Nicholas II in military suits, widely used in foreign encyclopedias and monographs.

\section{Political leaders of the USSR and Post-Soviet Russia}

The photos of leaders of the political parties which have appeared later, in the years of socialism, the victims of political repressions in the USSR, used in reference editions, are of particular interest. Thus, the figures concealed from Soviet science became literally visible, in many respects, thanks to foreign editions. In the encyclopedia of the Russian revolution history, H. Shukman placed the expressive photo titled "Stalin, Rykov, Kamenev and Zinoviev" which makes the readers wonder, who the executioners and who the victims were among the represented leaders of the party and Soviet elite of the country (Shukman, 1988, 167). 
Along with the photos of N.I. Bukharin, A.F. Kerensky, L.G. Kornilov, Kropotkin, P. N. Milyukov, S.A. Muromtsev, B. Savinkov, and V. M. Chernov, almost unknown in the USSR in the post-war years, American encyclopedias also published numerous photos of "the key figure of the Russian revolution", L.D. Trotsky. The well-known picture of Trotsky sentenced to imprisonment after defeat of the First Russian revolution was made by his lawyer. Another photo, especially popular among Western editions, is the 1917 photo of V.I. Lenin and L.D. Trotsky, taking part in a political meeting. Let us refer to the first version of "The American encyclopedia": "Lenin addresses to national crowd. Trotsky is behind him. Less gifted as a speaker, Lenin was more skillful and astute politician". In other versions of comments it was emphasized that Lenin was the one turned to the readers, speaking at the meeting, while the outstanding revolutionary Trotsky was standing to the right of the tribune, wearing a uniform. The connotations of the text illustrated by the photograph are rather positive: "the independent Marxist", "Lenin's right hand", "the hero of the revolution and a great commander", "the opponent in principle of Stalin in race for power". They helped to fix the image of the October armed revolt organizer, the defender of the socialist fatherland, the founder of the Workers' and Peasants' Red Army.

In the USA, photo albums by D. King's were published several times. The most known of his works is called "Commissar Vanishes". The book was translated into Russian and published in Russia twice: in 2005 and in 2012. The researcher managed to collect about 250 thousand photos of the Soviet era, with only a small part of the collection included into the book. The author reproduced the original picture of the party and Soviet elite and its retouched version. The disappearance of people from the photo meant their disappearance from political and physical life. The cover of the book was substantially illustrated. One photo of the USSR party elite was reproduced four times: in the last of the reproductions, from the whole group of leaders only J. Stalin is left standing.

The album visualized the way how the "thaw" period brought the "commissioners" back. In 1994, the editors of "The Cambridge Encyclopedia of Russia and the former Soviet Union" gave D. King an opportunity to include a special text and some visual material "Photos as Promotion" consisting of six original and retouched photos, into the book. For example, to illustrate the history between the years 1925 and 1949, five people of nine disappear from the photo of the party and Soviet elite.

In the designated years, foreign publishers exposed the forged photos which had been widely duplicated by the Soviet encyclopedic and educational editions. For example, in the USSR, the picture "Lenin and Stalin in Gorki" was of great popularity. In the West, it was often used with the following explanatory text: "During Stalin's age, this photo was used to demonstrate his close relations with Lenin. In reality the photo was skillfully forged by artists". The history of the forged picture was revealed in the latest universal American encyclopedia. It adequately presented the images of the victim of political repressions, almost unknown in Russia or among the political elite of the 1920-1980-s.

Many images of political leaders of the late Soviet and Post-Soviet era are deprived of lines of smart portraits and official pictures. Let us estimate the choice of pictures and descriptions to the photos or sketches of the first Soviet and first Russian president: "The American president B. Clinton laughs together with B. Yeltsin during a press conference", "Gorbachev walks with President Reagan across Red Square". 


\section{Pictures of Russian culture}

Literature, theater, ballet and music are admitted to be the four spheres of culture where Russians made the greatest contribution. Rather broad view on the history of Russian painting and sculpture of the Imperial period was presented by the last edition of the American encyclopedia of the $20^{\text {th }}$ century: A. Archipenko, L. Bakst, N. Gabo, V. Kandinsky, E. Levitsky, K. Malevich, A. Pevzner, I.E. Repin, A. Rublyov, S. Sautin, H. Soutine, V. Tatlin, P. Trubetskoy, P. Chelishchev. At the end of the last century and in the beginning of the $21^{\text {st }}$ century "The encyclopedia Americana" presented these artists and sculptors in the chapter called "Russian Art and Architecture". (The Encyclopedia Americana 2005, v. 30, p. 645-646).

Even small encyclopedic editions surely demonstrate reproductions of works by such Russian avant-garde artists as V. Kandinsky, K.Malevich, M.Shagal. Such expressions as "Russian ballet", "the Russian five" (composers), "Russian literature" did not only penetrate into the largest universal encyclopedias of the USA, but also found their place in the vocabulary as steady lexical units of English language.

It should be noted that in the consciousness of Western public Russia is mostly associated with the first-class examples of culture and names of Russian art masters. Moreover, cultural component was almost dominating in the positive perception of a modern country image.

\section{Russia and the USA: together and apart}

The theory of "places (figures) of memory" within so-called modern cultural history by Pierre Nora allowed him to make a peculiar inventory of places and figures of collective memory of France, form a methodological base for the latest researches. The "memory places" consist of "a material kernel", a changeable symbolic value and a functional task to create memories. Americans have their own view of the Russian figures and memory places.

Perhaps, the political history events are usually described within the dualistic opposition of "we vs. others", and sometimes more antagonistically, "we vs. enemies". This approach, common for historians, also means the promotion of "us" in the center of the event, while "others" only appear in the periphery, whatever the objective picture of the past is. A priori, the history of any country is presented within its system of values and goal-setting; therefore, the experience of "others" is perceived as alien and obviously unacceptable. The American view of Russian reality is reflected in the pictures "The Mir Station photographed from the shuttle "Atlantis", "Villagers in Vaselienka, Samara, kneel in thanks to American Relief Administration inspector". The photo of the main building of Moscow State University is titled "Russian Harvard". The photo of L.I. Brezhnev used in the latest American historical encyclopedia is made in the moment, when all the participants are overlooking the figure of American president R. Nixon, not himself. The sketch on the Caribbean Crisis is illustrated with a photo of some Soviet ships, made from a board of an American plane.

\section{Verbal comment to the images}

The text comment attached to the images surely includes information on the authorship of the material, the place of its storage, the image history. The verbal description is required to ensure the correct "reading" of the image by foreign readers. "Security guards of KGB on the governmental car pass ZIL on streets of Moscow", "The Russian statesman E. Primakov served to Boris Yeltsin as the Minister of Foreign Affairs, the prime minister and the real master of espionage". In the analysis of visual images in 
the American encyclopedia, the researcher notes the anthropocentric nature of the images once again.

Thus, the considered case of sources is of interest to the experts studying foreign historiography of Russia and historical imagenology. It can be useful for experts in the field of cross-cultural communication, as a visual image possesses rich communicative capacity.

American visual image of Russia significantly differs from the domestic: it is based on authentic pictures only, the attention is paid to ordinary life of Russians, the visual material is organized under the paradigm "This is the way we see Russia"; publishers help the reader "read" the historical picture correctly through a verbal comment. Encyclopedia authors follow the principle of decreasing detail: the visual material devoted to the events of the last decades is fuller and brighter.

The authors of the present article suggest that there is a great discovery awaiting the researchers of the experience of visualizing Russian history in the Eastern countries.

\section{References}

1. Belgorodskaya, L.V. 2013. Iconography of the House of Romanovs. Based on the materials of American Hillwood museum. 2013. № 2. Herald of an archivist (in Russian).

2. Vishlenkova, E. 2011.The Visual Ethnography of the Empire, or "Not Everyone is Allowed to See Russia". Moscow: UFO (in Russian).

3. Historian's Dictionary. 2011. Moscow: ROSSPEN (in Russian).

4. King, D. Commissar Vanished. 1997. Metropolitan Books.

5. Wortman, R.S. 2004. Scenarios of Power. Myths and Ceremony in Russian Monarchy. In 2 vol. Moscow: OGI (in Russian).

6. The Encyclopedia Americana. 2005. New York: Grolier.

7. The Encyclopedia of Russian History. 2004 . New York: Gale Group.

8. The New Encyclopedia Britannica. 1994. Chicago: Encyclopedia Britannica.

9. Shukman, H. 1988. The Blackwell Encyclopedia of the Russian Revolution. New York: Blackwell Ltd. 


\title{
Современный американский \\ визуальный образ российской истории
}

Л.В. Белгородская

Е.В. Тищенко ${ }^{\sigma}$, Т.А. Белгородская ${ }^{\mathrm{a}}$

${ }^{a}$ Сибирский федеральный университет Россия, 660041, Красноярск, пр. Свободный, 79

${ }^{6}$ Университет искусств в Лондоне 81 Sutherland, London, $W 92$ HG Great Britain

\begin{abstract}
Статья посвящена особенностям визуализации истории России в американских универсальныхиисторических энциклопедияхнарубеже ХХ-ХІвв. (Британника, Американская энцииклопедия, Энииклопедия истории России и др.) Охарактеризованы фонды и музеи, в которых хранятся использованные в этих изданиях изображения. Рассмотрен вопрос об отражении в изданиях природных, этнических особенностей страны, образов политической и культурной элиты государства. Дана оценка особенностей текстового комментария к приведенным изображениям.
\end{abstract}

Ключевые слова: американские энциклопедии, визуальный образ России.

Научная специальность: 07.00.00 - исторические науки. 